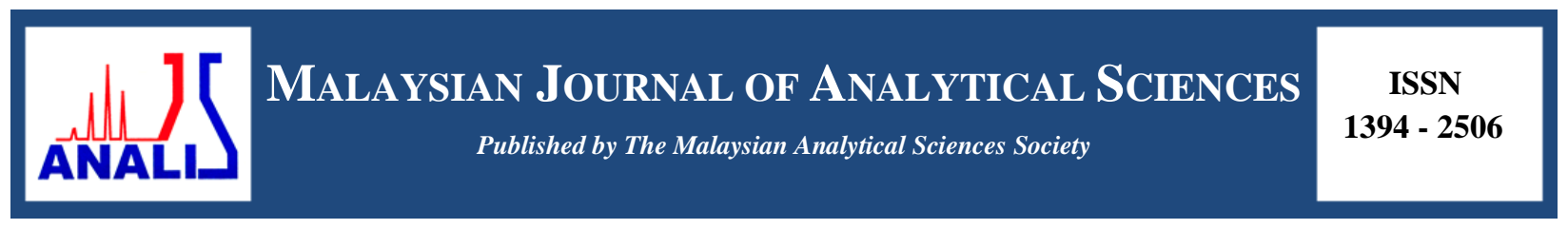

\title{
IMMOBILISED METAL AFFINITY CHROMATOGRAPHY (IMAC) BEADS FOR LYSOZYME SEPARATION: SYNTHESIS AND CHARACTERIZATION STUDY
}

\author{
(Kromatografi Afiniti Logam Dipegun (IMAC) untuk Pemisahan Lysozim: Sintesis dan Kajian \\ Pencirian)
}

\author{
Fatin Mohd Nasir ${ }^{1}$, Sofiah Hamzah ${ }^{1}$, Amirah Hamzah ${ }^{1}$, Nora’aini Ali ${ }^{1}$, Marinah Mohd Ariffin ${ }^{2}$ \\ ${ }^{1}$ School of Ocean Engineering \\ ${ }^{2}$ School of Marine Science and Environment \\ Universiti Malaysia Terengganu, 21030 Kuala Terengganu, Terengganu, Malaysia
}

*Corresponding author: sofiah@umt.edu.my

Received: 24 February 2015; Accepted: 27 October 2015

\begin{abstract}
Immobilized metal affinity chromatography (IMAC) has been established as a highly specific chromatographic technique for the production of enzymes and proteins including lysozyme. This study aimed to prepare and characterize the IMAC beads for lysozyme separation. Silica gel served as chromatographic matrix which has been coated with chitosan layer and crosslinked with glutaraldehyde (GTA-CTS-SiO 2$)$ since it is very convenient to promote fixation. Various IMAC ligands were immobilized by chelating $1500 \mathrm{mg} / \mathrm{l} \mathrm{Cu}{ }^{2+}, \mathrm{Zn}^{2+}, \mathrm{Fe}^{2+}, \mathrm{Fe}^{3+}$ and $\mathrm{Al}^{3+}$ ions, respectively on GTA-CTS-SiO 2 . IMAC which was immobilized with $1200 \mathrm{mg} / \mathrm{l} \mathrm{Cu}^{2+}$ exhibited the maximal immobilization capacity $(27.08 \mathrm{mg} / \mathrm{g})$ of within 30 minutes incubation time. This fundamental study can be a momentous pathway to develop an efficient chromatographic system for lysozyme separation in the future.
\end{abstract}

Keywords: silica gel, chitosan, glutaraldehyde, metal ions, copper (II) ion

\section{Abstrak}

Kromatografi afiniti logam dipegun (IMAC) telah diperlihatkan sebagai satu teknik kromatografi yang sangat spesifik untuk pengeluaran enzim dan protein termasuk lysozim. Kajian ini bertujuan untuk menyediakan dan mencirikan manik IMAC bagi tujuan pemisahan lysozim. Gel silika berperanan sebagai sokongan kepada kromatografi yang telah dilapisi dengan lapisan kitosan dan diaktifkan dengan glutaraldehid (GTA-CTS-SiO ${ }_{2}$ ) kerana kesesuaiannya yang berupaya menggalakkan lekatan. Beberapa ligan IMAC dengan kepekatan $1500 \mathrm{mg} / \mathrm{l}\left(\mathrm{Cu}^{2+}, \mathrm{Zn}^{2+}, \mathrm{Fe}^{2+}, \mathrm{Fe}^{3+}\right.$ dan $\mathrm{Al}^{3+}$ ion $)$ telah dipegunkan pada GTA-CTS-SiO . IMAC yang dipegunkan dengan kepekatan $1200 \mathrm{mg} / 1 \mathrm{Cu}^{2+}$ menunjukkan penjerapan kapasiti yang maksimum $(27.08 \mathrm{mg}) \mathrm{dalam}$ tempoh 30 minit masa pengeraman. Kajian asas ini boleh menjadi satu anjakan dalam langkah membangunkan sistem kromatografi yang berkesan untuk pengasingan lysozim pada masa akan datang.

Kata kunci: gel silika, kitosan, glutaraldehid, ion logam, ion kuprum (II)

\section{Introduction}

Currently lysozyme has been commercially become as an important enzyme used due to the high specificity, selectivity and efficiency function in the industries. Potent bacteriostatic and bactericidal properties of lysozyme give a huge impact as an antimicrobial agent [1] for the human body and as the food preservative especially in 
extension shelf life in food industries. Small amount of lysozyme makes the process of purification becomes challenge and intricate especially for the large scale production. Conventionally, separation of lysozyme has been obtained by several techniques such as ion exchange chromatography, ultrafiltration and affinity chromatography. However rigorous limitations occur including lengthy steps, complicated and expensive for large scale production has hampered the applications. Separation technique for protein by Immobilized Metal Affinity Chromatograph (IMAC) has established [2] due to the ligand stability, high adsorption capacity, mild elution condition, simple regeneration and low cost [3]. Selection of IMAC solid chromatographic matrix to entrap metal ions for the best serve as affinity ligands for various proteins such a critical attention in order to meet the requirement of high efficiency and fast flow operation. Conventional supports for IMAC are based on soft gel that coating with dextran and agarose give the compressible and restricted low flow rate in chromatography operations [4]. Upgrading matrix with porous silica as an ideal IMAC support which has high mechanical resistance, insolubility and available for long shelf life inorganic materials. To achieve the maximum protein adsorption, surface of silica beads are modified by coating with a hydrophilic and functional natural polymer. According to $\mathrm{Wu}$ et al, silica beads cross-linked with chitosan indicate convenient matches for metal ion adsorption [5].

Chitosan (CTS) is widely used for the hydrophilic modification due to its biocompatibility, biodegradability, chemical innertness, high mechanical strength and non-toxic material [6]. Besides, amino and hydroxyl groups in chitosan molecules supplied active reaction sites for the various functional ligands, therefore it considered as an excellent matrix for IMAC. However, chitosan required a cross-linker to modify chemical structure and textural properties by linking at the amine or the hydroxyl sites. Glutaraldehyde (GTA) is the best chosen cross-linker for chitosan which has a porous network that could improve adsorption properties and helped to form quaternary structure on the surface of the materials, thus increase the content of protonated amino groups [7] as well as improved the chemical stability of chitosan in acidic solution [8]. Practically, IMAC is depend on the formation of coordinate bonds between immobilized metal ions such as $\mathrm{Cu}^{2+}, \mathrm{Zn}^{2+}, \mathrm{Ni}^{2+}$, and $\mathrm{Fe}^{2+}$ with the functional groups of exposed amino acids on the surface of the target protein [9].

Inspired by previous researches, we have prepared IMAC beads with porous silica based characterized by chitosanglutaraldehyde modified polymer. ATR-FTIR was analysed to determine the binding of chitosan and crosslinking agent onto the silica beads. Then, modificated silica beads were studied the immobilized various metal ions sorption and the evaluation of optimum metal ion in different concentration by ICP-OES.

\section{Chemicals and materials}

\section{Materials and Methods}

Silica gels (70-230 mesh size) were obtained by Merck Millipore. Chitosan as a modified polymer and glutaraldehyde were purchased by Sigma Aldrich. Glacial acetic acid, sodium hydroxide, hydrochloric acid, dimethylsulphoxide (DMSO), copper (II) sulfate, calcium sulfate, iron (II) sulfate, iron (III) sulfate and zinc sulfate were analytical grade reagents commercially available and used without further purification.

\section{Preparation of chitosan coated silica beads}

Preparation of Chitosan-coated silica beads $\left(\mathrm{CTS}-\mathrm{SiO}_{2}\right)$ was according to Shi et al. [8] with some modification. Chitosan powder $(5 \mathrm{~g})$ was added into $250 \mathrm{ml}$ of $1 \mathrm{M}$ acetic acid and dissolved by magnetic stirring for several minutes at room temperature and finally, the prepared chitosan solution was stored in a Schott bottle at room temperature. Initiate with treated $50 \mathrm{~g}$ of silica beads with $20 \%$ of hydrochloric acid for 8 hours in incubator shaker at room temperature to obtain high adsorptive property of porous silica beads. The beads were rinsed with distilled water to remove the residual of hydrochloride inside silica beads and dried at $40{ }^{\circ} \mathrm{C}$ in oven. Prior to the surface coating, treated silica beads were immersed again into distilled water for 2 hours in order to wet the pore surface. An amount $10 \mathrm{~g}$ of silica beads were immersed into the chitosan solution and the flask containing the mixture was placed in the incubator shaker for the process of surface coating reaction at room temperature with $100 \mathrm{rpm}$ for 72 hours. Subsequently, immersed chitosan coated silica beads with dimethylsulphoxide (DMSO) for one hour to enhance polarity of the surface. Coated beads were then added into sodium hydroxide $(\mathrm{NaOH})$ solution $(\mathrm{pH} 8)$ for 2 hours to ensure solidify and fix the coating layer in the incubator shaker at $25^{\circ} \mathrm{C}$. 


\section{Beads activation and ligand immobilization}

CTS-SiO ${ }_{2}$ beads were cross-linking with glutaraldehyde which can be form a Schiff's base for chitosan. CTS-SiO beads were incubated in incubator shaker for 30 minutes in reacting solution containing $50 \mathrm{v} / \mathrm{v} \%(25 \%$ glutaraldehyde in $0.1 \mathrm{M} \mathrm{NaCl}$ and $0.1 \mathrm{M}$ sodium acetate-acetic acid buffer $\mathrm{pH} 7.4$ ) at room temperature. After adjusting $\mathrm{pH}$ to 6.0 by adding acetic acid, the flask was sealed and reaction was allowed to continue for 16 hours in the incubator at $25{ }^{\circ} \mathrm{C}$. When the reaction achieved, the excess GTA was removed by washing the beads with distilled water.

Activated silica beads (GTA-CTS-SiO ${ }_{2}$ ) were reacted with $0.1 \mathrm{M}$ of five metal ions; $\mathrm{CuSO}_{4}, \mathrm{FeSO}_{4}, \mathrm{Al}_{2}\left(\mathrm{SO}_{4}\right)^{3}$, $\mathrm{Fe}\left(\mathrm{SO}_{4}\right)^{3}$ and $\mathrm{ZnSO}_{4}$ respectively for 20 hours in incubator shaker $(100 \mathrm{rpm})$ at room temperature. The adsorbent were then rinsed with distilled water before storage or usage for the lysozyme adsorption. Prepared beads hereafter are called immobilized metal affinity chromatography (IMAC) beads. IMAC is operated based on the affinity adsorption between the metal-binding amino acids in the side chains of the proteins such as histidine, lysine, glutamic acid and etc as well as the metal ions including $\mathrm{Cu}^{2+}, \mathrm{Fe}^{3+}, \mathrm{Fe}^{2+}, \mathrm{Al}^{3+}$ and $\mathrm{Zn}^{2+}$ chelated by chelating ligand immobilized on the solid supports. The optimum metal ion immobilization has been chosen and verified the best concentration of metal ion before further studies with the evaluation performance of lysozyme adsorption.

\section{IMAC characterization}

Prepared IMAC beads were characterized in terms of morphology and the structure were observed using Scanning Electron Microscope (SEM), while the presence of elements has been analyzed by inductively coupled plasma optical emission spectrometry (ICP-OES) and the determination of functional groups for modified beads by using Attenuated Total Reflectance Fourier Transform Infra-Red Spectroscopy (ATR-FTIR).

\section{Adsorption studies}

After the metals concentration analysis using the ICP-OES, the amount of elements $\left(\mathrm{Cu}^{2+}, \mathrm{Fe}^{3+}, \mathrm{Fe}^{2+}, \mathrm{Al}^{3+}\right.$ and $\left.\mathrm{Zn}^{2+}\right)$ immobilized on the beads, $\mathrm{P}(\mathrm{mg} / \mathrm{g})$, were approximately calculated using the following equation 1 :

$$
\mathrm{P}(\mathrm{mg} / \mathrm{g})=\mathrm{V}(\mathrm{Co}-\mathrm{Ce}) / \mathrm{W}_{\mathrm{D}}
$$

where $\mathrm{Co}(\mathrm{mg} / \mathrm{l})$ is the initial elements concentration; $\mathrm{Ce}(\mathrm{mg} / \mathrm{l})$ is the final elements concentration after adsorption; $\mathrm{V}$ is the volume of the elements solution used; and $\mathrm{W}_{\mathrm{D}}(\mathrm{g})$ is the weight of beads.

\section{IMAC characterization}

\section{Results and Discussion}

IMAC beads were achieved in several stages including treating silica beads with hydrochloric acid, chitosan coating, cross-linking with glutaraldehyde and metal chelating. Chitosan mechanism interaction with silica beads been established [10] and the glutaraldehyde cross-linking could exhibit high operational stability of chitosan beads was coated [11]. Amination of the residue epoxy groups of could recover the loss of primary amino group during cross-linking with glutaraldehyde [12]. Hydrophilic characteristics of activated beads were improved the tendency of matrix for metal ion immobilization in the final stage of IMAC preparation. The surface morphologies of silica bead treated with hydrochloric acid is shown in Figure 1(a). The treated silica beads displayed smooth and channel like surface. The surface morphologies of silica beads modified with chitosan-glutaraldehyde represented in Figure 1(b) covered with a layer of rough surface as well as Figure 1(c) presented the rough and highly porous surface structure which can exhibit surface area and reducing the mass transfer resistance and facilitated the diffusion of protein molecules.

The ATR-FTIR spectra of native and modified silica beads are represented in Figure 2. The large broad stretching band around $3400 \mathrm{~cm}^{-1}$ corresponds to the associated $\mathrm{O}-\mathrm{H}$ stretching vibration of the hydroxyl groups and adsorbed water which means the hydrophilic character of the porous silica shown in Figure 2(a). The peaks at around 800 and $566 \mathrm{~cm}^{-1}$ are attributed to the typical symmetric and bending vibration of Si-O-Si in support framework of silica beads, respectively [13]. 



Figure 1. SEM micrograph of (a) silica bead treated with hydrochloric acid (b) modified silica beads with chitosan glutaraldehyde (c) IMAC absorbent

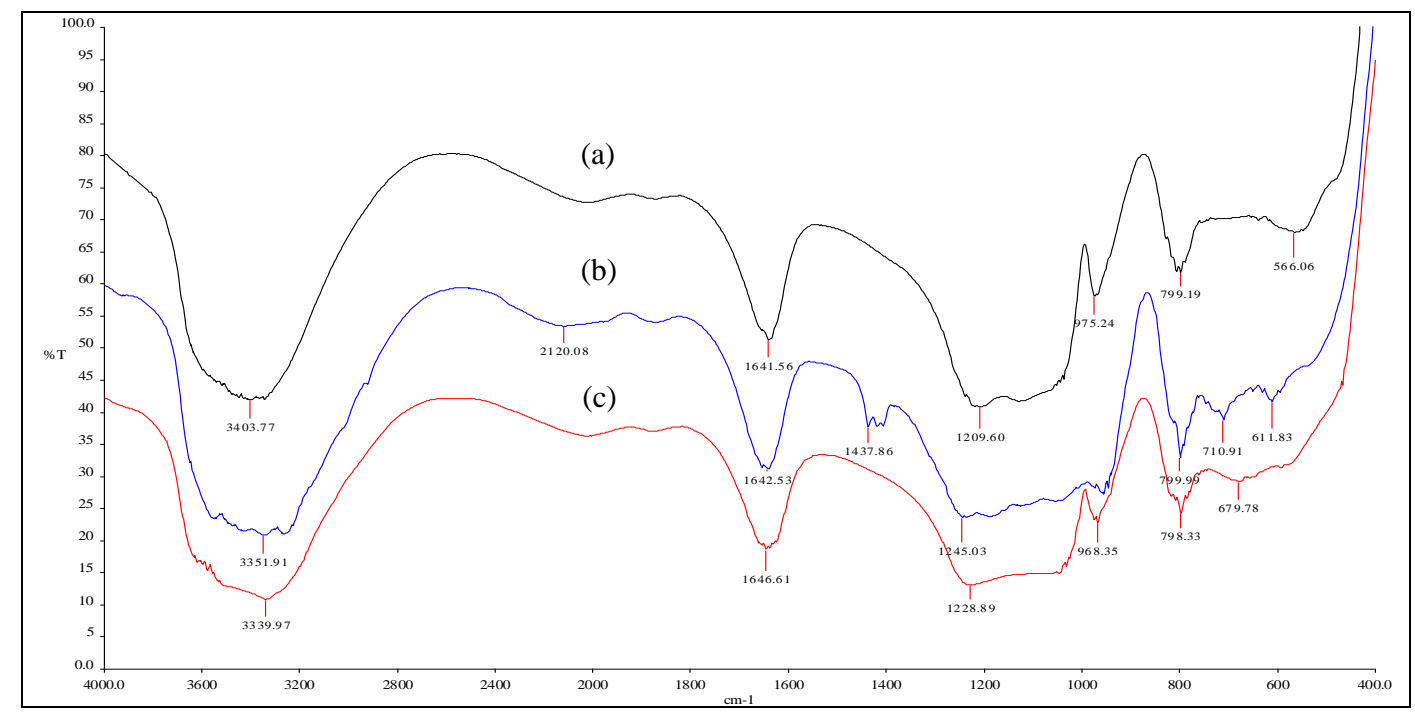

Figure 2. ATR-FTIR spectra (a) silica beads (b) chitosan coated beads (c) GTA-CTS-SiO

The band around $975 \mathrm{~cm}^{-1}$ from free silanol groups of silica disappeared or weakened after the modification (Figure 2(b)). The stretching vibration around $1640 \mathrm{~cm}^{-1}$ represent the $\mathrm{C}=\mathrm{N}$ in amine reaction between amino groups in 
silica and chitosan and aldehyde groups in glutaraldehyde [14]. The chitosan cross-linked with glutaraldehyde (Figure 2(c)) illustrated peaks at 968 and $1200 \mathrm{~cm}^{-1}$ assigned to saccharide structure. Hence, all peaks summarized the characterization of chitosan and glutaraldehyde for IMAC support.

\section{Immobilization capacity of metal ion onto IMAC matrix}

According to the IMAC separation concept, the use of metal ions that covalently bound chelating compound on a solid chromatographic matrix serves as affinity ligands that were vital to entrap optimum target proteins. Immobilization capacities studies of several kinds of metal ions were investigated in order to choose the most excellent metal ion among them. The chosen of metal ions; $\mathrm{Cu}^{2+}, \mathrm{Fe}^{2+}, \mathrm{Fe}^{3+}, \mathrm{Al}^{3+}$ and $\mathrm{Zn}^{2+}$ ions rather than $\mathrm{Ni}^{2+}$ which is usually used in IMAC technique and has higher binding affinity for protein because of the leaking $\mathrm{Ni}^{2+}$ ions could cause human carcinogenic even in trace amount [15]. In this study, the GTA-CTS-SiO ${ }_{2}$ beads were used as IMAC supports and immobilization of ligand (metal ion) displayed in Figure 3.

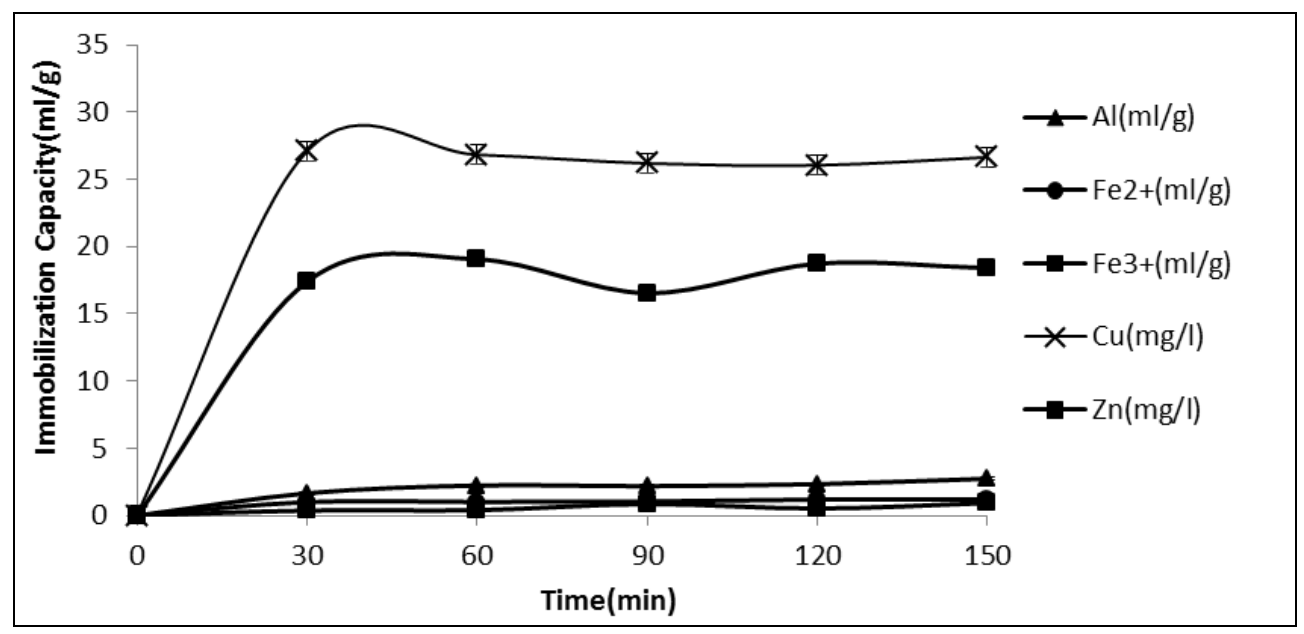

Figure 3. Immobilization capacity of metal ions

The capacity of $\mathrm{Fe}^{3+}, \mathrm{Fe}^{2+}$ and $\mathrm{Al}^{3+}$ ions adsorption is the lower than surfactant modified chitosan beads. Those metal ions might not suitable for the chitosan coated beads adsorption. $\mathrm{Fe}^{3+}$ and $\mathrm{Al}^{3+}$ have been used for Orthophosphoserine (OPS) chelating compounds for immobilization in IMAC [16]. The adsorption capacities for $\mathrm{Zn}^{2+}$ is lower than $\mathrm{Cu}^{2+}$ otherwise still give high adsorbent amount. The maximal adsorption achieved at 30 minutes of incubation time. Obviously, $\mathrm{Cu}^{2+}$ is the high immobilized metal ion towards the GTA-CTS- $\mathrm{SiO}_{2}$ with the maximal capacity $28.07 \mathrm{mg} / \mathrm{g}$ within the optimum time incubation, 30 minutes. The apparent affinity of a protein for a metal chelate depends strongly on metal ions involved in coordination. To fulfil the requirement of high protein adsorption onto the IMAC beads, the particular concentration of metal ion need to be obtained.

The principle of IMAC towards the immobilization of protein on IMAC beads were mainly through the coordination between metal ions with electron donating side chain of residues such as histidine and crysteine hence known as important factors in determining the absolute concentration of immobilized metal ion [17].

Based on the calculated values which is analysed by ICP-OES, the optimum concentration amount that ideal to the IMAC beads is $1200 \mathrm{mg} / \mathrm{l}$ with maximal adsorption amount $286.11 \mathrm{mg} / \mathrm{g}$ (Figure 4). It shown that efficient ligand immobilization could be achieved when $1200 \mathrm{mg} / \mathrm{l}$ ligand were utilized. An increased of ligand concentration up to $1500 \mathrm{mg} / \mathrm{l}$ tend to the formation of precipitation due to the excess of $\mathrm{Cu}$ (II) and also effected the adsorption of further protein. This optimum concentration of ligand provided higher surface area and accessible for lysozyme to bind. The lower concentration of glutaraldehyde was maintained to give the sufficient amount of free amino groups of $\mathrm{Cu}^{2+}$ interaction on the chitosan beads as well as yielded better adsorption capacity. The glutaraldehyde method 
was served high endurance for the ligand immobilization [18]. Furthermore, $\mathrm{Cu}^{2+}$ adsorption was performed excellent at neutral $\mathrm{pH}$ to avoid the formation of $\mathrm{Cu}^{2+}$ hydroxide which could affect the adsorption capacity for the further protein recovery.

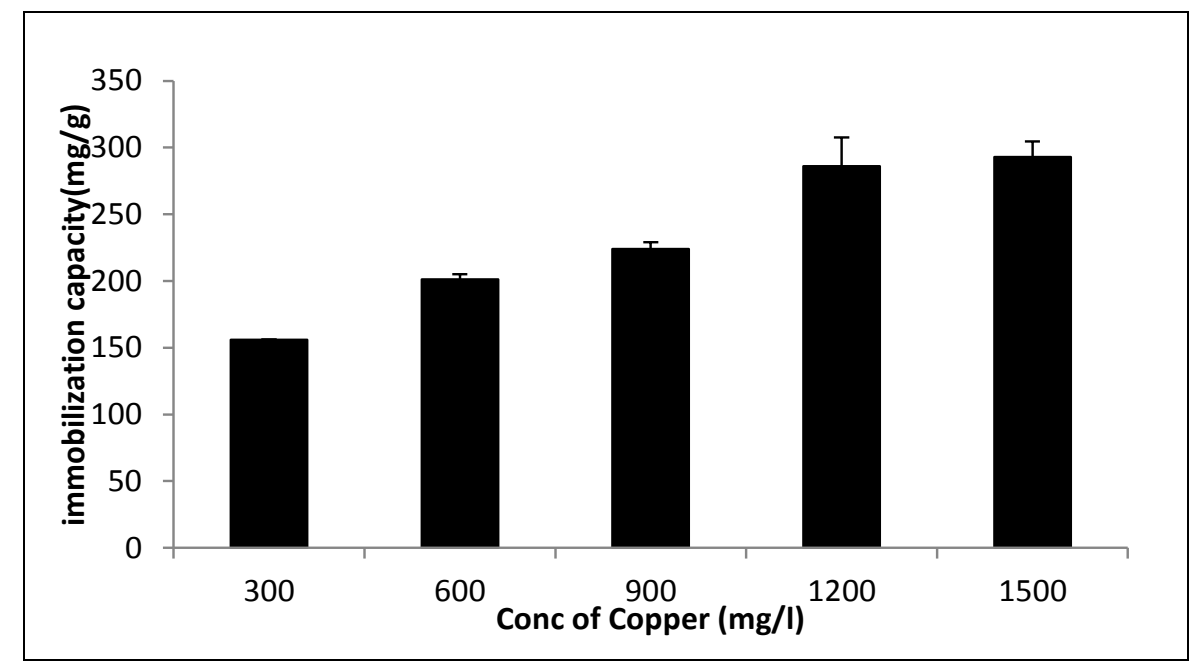

Figure 4. Immobilization capacity on different concentration of copper (II) ion

\section{Conclusion}

Preparation and characterization of IMAC beads were successfully performed by modification of silica beads with chitosan and glutaraldehyde as activated cross-linked. The morphology of modified polymer and IMAC absorbent was visualized by SEM and followed with the ATR-FTIR analysis, which was verified the presence of chitosan, glutaraldehyde and $\mathrm{Cu}^{2+}$ onto the IMAC surface. Maximum immobilization capacity of metal ion obtained using $\mathrm{Cu}^{2+}$ at $1200 \mathrm{mg} / \mathrm{l}$ and this finding could be used for further application of lysozyme adsorption.

\section{Acknowledgement}

The authors would like to express a high gratitude to Ministry of Higher Education Malaysia for the funding of this research (ERGS 55097) and University Malaysia Terengganu (UMT) for all supports and contribution.

\section{References}

1. Evrim, B. A., Nalan, T., Candan, N. and Adil, D. (2007). Use of magnetic poly(glycidyl methacrylate) monosize beads for the purification of lysozyme in batch system. Journal of Chromatography, 853(1-2): 105 113.

2. Mooney, J. T., Fredericks, D. P., Hearn and Milton T. W. (2013). Application of an IMAC cassette for the purification of N-terminally tagged proteins. Separation and Purification Technology, 120: 265 -274.

3. Arnold F. H. (1991). Metal affinity separations: a new dimension in protein processing. Biotechnology, 9 (2): $151-156$.

4. Gaberc-Porekar, V. and Menart, V. (2001). Perspectives of immobilized-metal affinity chromatography. Journal Biochemical and Biophysical Methods, 49 (1-3): 335 - 360.

5. Wu, F., Zhu, Y. and Jia Z. (2006). Preparation of dye-ligand affinity chromatographic packing's based on monodisperse poly (glycidylmethacrylate-coethylenedimethacrylate) beads and their chromatographic properties. Journal Chromatography A, 1134(1-2): $45-50$.

6. Tan, T. W., Xu, W. J. and Zhang, S. R. (1997). The synthesis of chitosan coated affinity chromatography absorbent. Ion Exchange Adsorption. 13: 141 - 146.

7. Rose, D., Jöris, J., Hackermüller, J., Reiche, K., Li, Q. and Stadler, P. F.(2008). Duplicated RNA genes in teleost fish genomes. Journal of Bioinformatics and Computational Biology, 6(6): 1157 - 1175. 
8. Shi, Q-H, Tian, Y, Dong, X-Y, Bai, S. and Sun. Y. (2003). Chitosan-coated silica beads as immobilized metal affinity support for protein adsorption. Biochemical Engineering Journal, 16: 317 - 322.

9. Xi, F. N. and Wu, J. M. (2004). Macroporous chitosan layer coated on non-porous silica gel as a support for metal chelate affinity chromatographic adsorbent. Journal Chromatography A, 1057: 41 - 47.

10. Singla, A. K. and Chawla, M. (2001). Chitosan: some pharmaceutical and biological aspects - an update. Journal of Pharmacy and Pharmacology, 53: 1047 - 1067.

11. Lee, Y. M., Nam, S. Y. and Woo, D. J. (1998). PV performance of $\beta$-chitosan membrane for water/alcohol mixtures. Journal of Polymer Engineering, 18(12): 131 - 146.

12. Altun, G. D and Cetinus, S. A. (2007). Immobilization of pepsin on chitosan beads. Food Chemistry 100: 964 -971 .

13. Qu, R., Zhang,Y., Qu, W., Sun, C., Chen, J., Ping, Y., Chen, H. and Niu, Y. (2013). Mercury adsorption by sulfur- and amidoxime-containing bifunctional silica gel based hybrid materials. Chemical Engineering Journal, 219: $51-61$.

14. Cetinus, S. A., Sßahin, E. and Saraydin, D., (2009). Preparation of $\mathrm{Cu}(\mathrm{II})$ adsorbed chitosan beads for catalase immobilization. Food Chemistry, 114: $962-969$.

15. Bal, W., Liang, R., Lukszo, J., Lee, S. H., Dizdaroglu, M. and Kasprzak, K. S. (2000). Ni(II) specifically cleaves the C-Terminal tail of the major variant of histone H2A and forms an oxidative damage-mediating complex with the cleaved-off octapeptide. Chemistry Research Toxicology, 13(7): 616-624.

16. Zachariou, M, Traverso, I. and Hearn, M. T. (1993). High-performance liquid chromatography of amino acids, peptides and proteins. CXXXI. O-phosphoserine as a new chelating ligand for use with hard Lewis metal ions in the immobilized-metal affinity chromatography of proteins. Journal of Chromatography, 646(1): 107 - 120.

17. Sun, J., H. Ma, Y. Liu, Y. Su, W. Xia and Yang, Y. (2012). Improved preparation of immobilized trypsin on superparamagnetic nanoparticles decorated with metal ions. Colloids Surfaces A: Physicochemical Engineering Aspects, 414: 190 - 197.

18. Guo, W. and Ruckenstein, E. (2003). Crosslinked glass fiber affinity membrane chromatography and its application to fibronectin separation. Journal Chromatography B,795: 61 - 72 